\title{
In Memorium: Robert W. Fogel
}

Robert W. Fogel was a visionary economic historian, generous mentor, and eternal optimist whose works and lectures have informed and incited for more than half a century and whose writings will continue to do so for decades to come. He died on June 11, 2013 in his eighty-sixth year. He had co-taught a graduate course at the University of Chicago that quarter and in the weeks before he died he was planning his fall 2013 teaching. "I've often told my students I'm not retiring. You're going to have to carry me out in a wooden box. I'm having too much fun," he remarked to a recent class.

His fun was palpable to others and his enormous enthusiasm for the material he taught overflowed to his audience. Legendary for encouraging students to pursue their ideas, he was an eternal optimist about their abilities and projects. Bob had a fine sense of humor and his chuckle was an integral part of his speech. He was known for his generosity and humanity. A scholar of high standards, he often leavened criticism of students with a rare gentleness.

He taught by example the importance of being more interested in what others are doing than in oneself and that social time is a critical input to scholarly time. No matter how busy he was, he always found time to engage with others. No opinion was too small to debate and no person too inconsequential to engage with. He was, as well, an institution builder. He founded the Development of the American Economy Program at the National Bureau of Economic Research in 1978 and it thrives until today. He established the Center for Population Economics at the University of Chicago, although it has, sadly, passed along with him. Bob thought big both in terms of his projects and the apparatus that buttressed them.

How Bob accomplished so much was due to his exceptional mind, laser beam vision, and extraordinary work ethic. It has been said that when the Nobel committee called him around 5:30am he was already up working in his office, as he was every day.

\section{THE FOGEL SYSTEM OF RESEARCH}

The Fogel system of research is characterized, in the first instance, by a question of contemporary relevance that requires the long lens of history. The issues examined are big and are those that have engaged generations of scholars. Because there are already a host of potential answers for the question and generally one that has dominated the literature, the Fogel system creates a "counterfactual." If the answer proposed to question $Y$ is $X(Y=$ what caused economic growth? and $X=$ railroads), then the Fogel system must prove that if not for $X$ (railroads) the premise of question $Y$ would not have occurred (there would have been far less economic growth). Finally, the Fogel system takes what appears to be an intractable problem (e.g., creating an economy without the railroad) and simplifies the answer into a single number.

Although the counterfactual is most associated with Fogel's work on the railroads, it is also imbedded in his other work. Much of the work on slavery addressed the counterfactual: "Had slavery not existed in the United States, the South would have been a wealthier region." That was the claim of many whose writings preceded Time on the Cross. In his work on standards of living, the implicit counterfactual was:

Reprinted by permission from EH.News@eh.net.

This remembrance of Robert W. Fogel's contributions to economic history was put together for the Economic History Association by Dora Costa, Claudia Goldin, and Robert A. Margo. 
"Had incomes not risen in eighteenth-century Europe, mortality and morbidity would have been markedly worse." In this case, the counterfactual was shown to have been true. Moreover, use of counterfactuals is inescapable. If, as Fogel believed, the long lens of history is needed to inform the present, one must ask what the present would look like without some part of the long lens. Each of the three major research projects of his career illustrates this fundamental methodological point.

\section{THE PROJECTS}

Bob's reputation was largely made by his $\mathrm{Ph} . \mathrm{D}$. dissertation on the railroads. He estimated that the "social savings of the railroad," including both the interregional and intraregional portions, was between 6 and 7 percent of 1890 GNP. ${ }^{1}$ Whether that is a large or small number is in the eyes of the beholder. But to many it was a small number relative to prior claims that the railroad was indispensable to American economic growth. The main reason the estimate is not larger is that there were many substitutes for the railroad in the United States in the form of water transportation. The social savings was much higher in places like Mexico where there were poorer substitutes for the railroad.

But Railroads and American Economic Growth went far beyond measuring the aggregate "treatment effect" of the Iron Horse. The idea of jumpstarting economic growth was a popular notion in the 1950s and big infrastructure projects were a potential lever for developing nations. As a graduate student at Johns Hopkins, Fogel had actively debated the work of Walt Rostow with his classmate Stan Engerman. According to Rostow, an economy could "take off" because of a single innovation and, moreover, America did take off in the 1840s through the railroad's many backward linkages. On the contrary, demonstrated Fogel, there was no take off and backward linkages were neither extensive nor critical to growth in other sectors. The railroads were not a magic bullet for economic growth because there are no magic bullets.

The Ivory Tower of the 1960s was no scholarly oasis from the intrusions of the real, political world. Married to an African American woman, Bob could not escape heated discussion of Civil Rights even at the dinner table. Stan Engerman and he embraced the topic of slavery with all of its potential social and political improprieties. Would slavery have died out, without a protracted, bloody, divisive, and costly Civil War? No, because slavery was profitable and viable. Was the relative poverty of the postCivil War South a mere extension of slavery? No, because the per capita income of antebellum white southerners was about equal to that of Midwestern farmers and because the southern economy grew at the national average between 1840 and 1860 . Were slave owners the principal economic beneficiaries of the Peculiar Institution because they ruthlessly "exploited" their chattel? The answer is more complicated. Fogel and Engerman uncovered precisely why the force of slavery produced enormous wealth. The gang system made cotton and other staple crops cheaper and all of this eventually benefited consumers through lower prices. Fogel and Engerman also maintained there was a record of black achievement during and after slavery that deserved celebration. As expressed in the frontispiece to Time on the Cross

\footnotetext{
${ }^{1}$ These figures add the interregional and intraregional estimates and use a blow up factor of four. The intraregional estimates are those with new canals and road resurfacing. The lower figure takes some land out of cultivation and the higher one does not.
} 
- a dedication to Bob's wife Enid, who predeceased him-"To Mary Elizabeth Morgan's first daughter: She has always known that black is beautiful."

Time on the Cross was applauded initially but backlash soon followed. Throughout the give-and-take of the often acrimonious debate Bob and Stan maintained their good cheer and fundamental optimism that the scholarly dispute was to everyone's benefit. "It was an exchange," Bob wrote in Without Consent or Contract, "in which there were no losers." Without Consent clarified that the ultimate issues of slavery were moral and that confronting these linked the historical study of slavery to the moral issues of the modern American dilemma. Slavery was an abomination not because it was economically moribund but because slaves were denied basic human rights. The abomination was perpetuated across generations and was assisted by institutionalized racism after the Civil War. The moral indictment of racial discrimination and segregation underlying the Civil Rights Movement forms a continuum with Fogel's moral indictment of slavery.

Work on slave living standards suggested that adult height could be used an indicator of health and wellbeing. Preliminary research, completed in 1978, with numerous co-authors showed deterioration in the heights and life expectation of whites in the mid-nineteenth century. The finding led to an exploration of archival data that could help improve our understanding of health and mortality changes from 1650 to 1910. That search unearthed the military records in the U.S. National Archives and Bob's realization that longitudinal data for the first cohort to reach age 65 in the twentieth century could be created by combining wartime service, pension, and census records of Union Army soldiers.

The Union Army project illustrates Bob's dictum: "If it's worth doing, it's worth spending ten years of your life doing it right." A project to collect the records of Union Army soldiers to study the effects of wartime and early life stress on older age mortality and morbidity, as well as the determinants of retirement, was proposed in 1986. Funded in 1991 by the National Institute of Aging as Early Indicators of Later Work Levels, Disease, and Death, the project was renewed many times and was ongoing at the time of Fogel's death. To date, the project has made available (at uadata.org), the life histories of 39,000 white Union Army soldiers, 6,000 black Union Army soldiers, and detailed ward maps and ward statistics for selected cities. The project is currently collecting the records of an additional 15,000 black Union Army soldiers and of Union Army soldiers who grew up in the large and unhealthy cities of the time and of those who lived to at least 95 years.

Findings from this research program on the health of men in the past led Bob to formulate a theory that he called "technophysio evolution," described most recently in The Changing Body. Adjustments to adverse conditions including a limited food supply, Bob argued, do not occur through crisis mortality but, rather, through chronic starvation producing a thin, stunted population. The Bastille, according to Bob's memorable image, was stormed by underweight Lilliputians. Bob viewed the relationship between health and economic growth as an intergenerational one. Nutritional status (a function of both nutritional intake and the demands made on that intake by work and disease) determines longevity and current work levels. Work levels and intensity plus technology determine output. Output in turn determines living standards and technological investments. The standard of living in turn determines the nutritional status of the next generation.

Robert Fogel always made time in his full and demanding life for meaningful hobbies in woodworking and photography, both of which were pursued at highly skilled levels. His pastimes and scholarship shared an essential feature. An artful table has pleasing proportions, intricate detail, and functionality. A masterful photograph 
is a thoughtful, well-composed window on a larger world. Robert Fogel's outstanding attribute as a scholar was his ability to visualize and orchestrate the complete architecture of a project, each piece polished and in its proper place with the whole greater than the sum of the parts. He could envision his research in final form long before any of the parts were complete. In this he has no peers.

We were his students as his career was taking off and in full swing. He then became famous, was awarded the Nobel, and had many demands on his time. He also aged and developed various infirmities. Bob always stressed the importance of family and his many students are like a family. As he once said: "It is difficult to be orphaned at any age." We take solace and pleasure in the statement of a recent student that: "He was the best of scholars and a caring teacher." He was that — and more- for us.

Dora Costa, Claudia Goldin, And Robert A. Margo

\section{REFERENCES}

Floud, Roderick, Robert W. Fogel, Bernard Harris, and Sok Chul Hong. The Changing Body: Health, Nutrition, and Human Development in the Western World Since 1700. NBER Series on Long-Term Factors in Economic Development. Cambridge: Cambridge University Press, 2011.

Fogel, Robert W. Railroads and American Economic Growth: Essays in Econometric History. Baltimore, MD: Johns Hopkins Press, 1964. . Without Consent or Contract: The Rise and Fall of American Slavery. New York: W.W. Norton and Company, 1989.

Fogel, Robert W., and Stanley L. Engerman. Time on the Cross: Evidence and Methods, a Supplement. Boston: Little Brown and Company, 1974a. . Time on the Cross: The Economics of American Negro Slavery. Boston: Little Brown and Company, 1974b. 